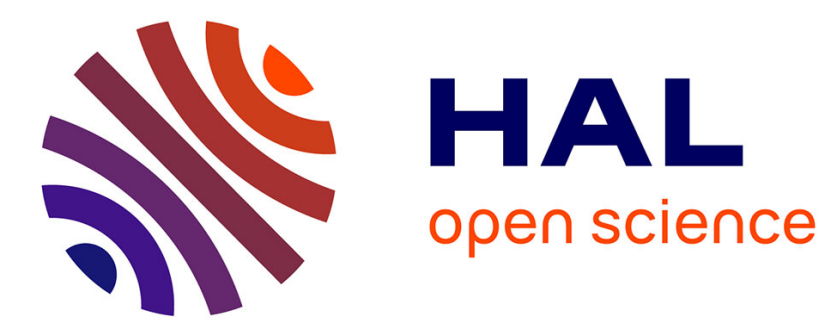

\title{
Modern Law and Arab Societies in Recent French-Speaking Literature
}

Baudouin Dupret

\section{To cite this version:}

Baudouin Dupret. Modern Law and Arab Societies in Recent French-Speaking Literature. Journal of Law and Religion, 2001. hal-02632328

\section{HAL Id: hal-02632328 \\ https://hal.science/hal-02632328}

Submitted on 27 May 2020

HAL is a multi-disciplinary open access archive for the deposit and dissemination of scientific research documents, whether they are published or not. The documents may come from teaching and research institutions in France or abroad, or from public or private research centers.
L'archive ouverte pluridisciplinaire HAL, est destinée au dépôt et à la diffusion de documents scientifiques de niveau recherche, publiés ou non, émanant des établissements d'enseignement et de recherche français ou étrangers, des laboratoires publics ou privés. 


\section{MODERN LAW AND ARAB SOCIETIES IN RECENT FRENCH-SPEAKING LITERATURE January 17, 2001}

\section{Baudouin Dupret Centre National de la Recherche Scientifique (CNRS), Centre d'Etudes et de Documentation Economique, Juridique et Sociale (CEDEJ), Cairo}

It is only recently that French research has considered law in Arab countries anew, from a point of view that is not strictly juristic or positivist. Islamic studies in Europe were traditionally very much interested in the study of Islamic law, for the practical objective of administrating colonizing countries or for the more culturalist reason that law was considered the core of Islamic civilization. ${ }^{1}$ This interest in Islamic law gave birth to a huge literature whose achievements should not be overlooked. It was, however, mainly focused on scriptural law, i.e., the law of jurists and of fiqh books. Prominent figures like Yvon Linant de Bellefonds, Emil Tyan, and Louis Milliot wrote books that are still resourceful for research, but they all fell into the trap of essentializing a scholarly produced law without giving an account of legal practices and variations from time to time and place to place. René Maunier and Jacques Berque were notable exceptions with regard to that attitude toward Islamic law. Post-independence legal thinking became even more positivist. Among the many factors explaining this trend, one should stress what Michel Camau called the crafting of a prospective law, that is a law whose ideological component is oriented toward the transformation of a society and the construction of a state, to the prejudice of its organizational component, i.e. the way in which law attempts to reflect and to regulate actual social structures. Duplicating French legal codes, training lawyers in France and resorting to French lawyers for teaching law did not help to restore the balance. It is only in Morocco, under the influence of an ethnographic paradigm, that we can observe some evidence of a strong attention directed toward social practices. Some pioneers like Najib Bouderbala and Paul Pascon, Omar Azziman, and Abdallah Hammoudi devoted their work to the relationship between law and fact. In a seminal article in 1972 , Bouderbala and Pascon called this relationship "Le droit et le fait dans la société composite." However, as a whole, legal research reflected the more general problem of the French tradition, which is very much under the influence of the codification of law and of a positivist conception of law.

Things have changed slightly, beginning in the late 1980s, after a real rebirth of research in France, devoted to legal and normative phenomena. With regard to modern Middle Eastern and Islamic law, a small group of scholars in Aix-en-Provence initiated a network of French and North African researchers that resulted in some 
collective books and journals. These publications are valuable not only for the content of their contributions, but also for the change of attitude they reflected. The first of these books was L'enseignement du droit musulman (The Teaching of Islamic Law) (1). ${ }^{2}$ The publication of this volume was the outcome of a seminar that focused on the legal field in the Arab world. ${ }^{3}$ The title of this book does not reflect its content: besides a few contributions devoted to Islamic legal education, it mainly addresses the meaning of Islamic law in a changing modern context. The book discloses the enormous stakes at issue in the project of broad transformation of Islamic law.

Originating from the same network of researchers who are increasingly interested in law from a sociopolitical perspective, Droit et environnement social au Maghreb (Law and Social Environment in the Maghreb)(2), edited by Omar Azziman (though his name does not appear on the cover), is a collection of contributions from authors who mainly came from North African countries. ${ }^{4}$ By its juxtaposition of very different types of papers, i.e., legal studies and socio-legal studies, it reflected the ambivalence of what was at that time a very new trend. At the same time, it also showed how dynamic legal research was in the countries of the Maghreb, though the impetus of a vivid anthropological legacy and an increasingly acute awareness of the need to bridge the gap between law within scholarly discourse and law reflecting daily concerns in human society. In his introduction, Omar Azziman pointed to the following fundamental aspects of this new approach to the legal phenomenon in the Arab Muslim context: focusing on law as a social fact, denying the dogma of legal autonomy, looking for legal production where it occurs and not only within the state, stressing the historical dimension of law, and adopting a critical point of view.

The main themes and trends of L'enseignement du droit musulman and Droit et environnement social au Maghreb also constituted the topic of a special issue of the French review Droit et société (3). ${ }^{5}$ This issue of the

\footnotetext{
${ }^{1}$ I want to address my most grateful thanks to Edward Gaffney and his team for the wonderful job they made in painstakingly editing this essay.

2 The following contributed: Babadji R., 'Abd al-Fattah N., Botiveau B., Qallada W.S., Derouiche-Ben Achour S., Filali Meknassi R., Jacquemond R., Bouraoui S., Henry J.-R., Abû Tâlib S., Laghmani S., Khayati $M$. number within parentheses after a book refer to the bibliography below.
}

${ }^{3}$ Al-Ahnaf M., Botiveau B. et Cesari J. The following scholars contributed to this book: J. Deprez, B. Fillion, M. Flory, J.-R. Henry, H. Bleuchot, H. Sanson, C. Bontems, L. Bousquet-Lefèvre, M. Robine, B. Botiveau, M.N. Mahieddin, M. El Hatimi, A. Kassis, P.-S. Agate, J.-F. Rycx, S. Chaker and F. Castro.

4 List of contributors: Ahmed Mahiou, Yadh Ben Achour, Khalid Naciri, Mohamed Tozy, Ali Mekouar, Jean-Robert Henry, Mohamed Guessous, Abderrazak Moulay R'Chid, Abdallah Saaf, Jean Deprez, Mohamed Charfi.

5 List of contributors: Jean-Robert Henry, Soukeina Bouraoui, Sana Ben Achour-Derouiche, Sadok Belaïd, Slim Laghmani, Bernard Botiveau. Hervé Bleuchot, Ramdane Babadji, Mohamed Tozy, Mohamed Mahdi, Hélène Claudot-Hawad. 
journal considered law in a broader framework, including political science, sociology and anthropology. The plural character of law as intertwining normative orders was also fully assessed. Summarizing his contribution, JeanRobert Henry stressed that "law is now a major cultural stake. This pertains to the twofold nature of law, which is always both a condensation of social culture and an instrument of transforming or preserving values. When applied to a compound normative network, this ambivalence provides to users a greater capacity of 'variance,' which is to say a capacity of playing on different registers to enhance their juridical experience and express their expected identities." The last major production of this network is a collective book published in 1994 by the Centre d'Etudes et de Documentation Economique, Juridique et Sociale (CEDEJ, Cairo, Egypt) following a workshop in Cairo in 1990. CEDEJ is the heir of the old Ecole Française du droit established in 1890 and closed in 1956. It inherited a library with an excellent collection of legal literature, and it hosts research fellows who spend several years in Egypt studying its legal system as well as the uses and practices of law in its social and political context. The book, entitled Politiques législatives: Egypte, Tunisie, Algérie, Maroc (Legislative Politics: Egypt, Tunisia, Algeria and Morocco) (4) aimed at assessing how modern law was first conceived and then challenged in several Arab countries. $^{6}$ It constitutes a good contribution to the analysis of the changes that affected legal construction, discourse, and practices under the sway of Islamic political contest. It also revealed a strong interest in the political dimension of legal argument, something reflected in a special issue of the review Monde arabe Maghreb Machrek (7) on the political uses of law. ${ }^{7}$

Bernard Botiveau's book Loi islamique et droit dans les sociétés arabes (Islamic Law and Positive Law in Arab Societies: Mutations of Judicial Systems in the Middle East) (6) represented a major step in changing the scholarly gaze toward law in Arab societies. Botiveau's endeavor is grounded on three important assumptions. First, it is necessary to think about the status of Islamic law as a way to produce knowledge and views on the world. Second, it is legitimate to assess the impact of secularization and codification on law, so that the current dynamics of "re-Islamizing" law and political institutions cannot be understood simply in terms of a "return to sources." Finally, legal anthropology constitutes a major tool in the study of law in general and in the Arab world in particular. The

\footnotetext{
${ }^{6}$ List of contributors: Ramdane Babadji, Nabil 'Abd al-Fattah, Bernard Botiveau. William Sulayman. Qallada, Sana Derouiche-Ben Achour, Rachic Filali Meknassi, Richard Jacquemond, Soukeïna Bouraoui, Jean-Robert Henry, Sufi Abu Talib, Slim Laghmani, Mustafa Khayati.
}

${ }^{7}$ Mohamed Al-Ahnaf, Bernard Botiveau and Jocelyne Cesari contributed to this issue. 
book focuses, moreover, on very important elements of legal change: legal education, codification, legal professions, strategies of litigants before the courts, competing sources in the crafting of legal knowledge. It does not necessarily mean that law is stuck in a kind of schizophrenia with a state attempting at "modernizing" institutions and societies struggling against such an imposed modernization.

Hervé Bleuchot's book on law in Sudan from an anthropological perspective is another testimony of this new attention devoted by French-speaking scholars to socio-legal studies in the Arab Muslim world. Les cultures contre l'homme? Essai d'anthropologie historique du droit pénal soudanais (Cultures Against Humanity? An Essay of Historical Anthropology on Sudanese Criminal Law) (8) constitutes a bold attempt to address both the legal history of Sudan and fundamental concepts of legal anthropology. It suffers, however, from many flaws. For example, Bleuchot holds that in order to analyze legal developments in Sudan, one must offer a general introduction to something like Islamic law as a whole, or must use legal texts as basic anthropological and quasi-exclusive references, or must evaluate current laws in terms of their conformity with a so-called original and true Islamic legal tradition. Nonetheless, his work reflects the profound shift in outlook that has taken place in French-speaking scholarship with respect to law in general and to law in the Middle East in particular.

This is also the case with L'Etat de droit dans le monde arabe (The Rule of Law in the Arab World) (11), a collective book following a conference in Aix-en-Provence in $1994 .^{8}$ Its editor, Ahmed Mahiou, is a lawyer and not a social scientist; and the topic itself, i.e., the rule of law, traditionally belongs to legal and political philosophy. Nevertheless, many contributions to this book address the question of law from the perspective of social and political sciences, speaking of its agents, their strategies, the resources they mobilize and so forth. This book also reflects the ambiguities of research ensconced in the process of evaluating the very concrete level of Arab experiences with reference to the very abstract level of the paradigms of political philosophy. In that sense, this book illustrates the difficulties in trying to do proper field work on Middle Eastern and Islamic law.

Marie-Claire Foblets is among the first scholars who contributed an anthropological study to the field. Her work focuses not on the Middle East, but on mainly North African Muslim migrant communities in Belgium. In Les familles maghrébines et la justice in Belgique. Anthropologie juridique et immigration (Maghrebian Families and

\footnotetext{
${ }^{8}$ Hervé Bleuchot, Hossam Issa, Mohamed Mouaqit, Gérard Groc, Noureddine Sraïeb, Habib Ishow, Jocelyne Cesari, Ahmed Salem Ould Bouboutt, Maurice Flory, Ahmed Mahiou, Michel Miaille, Madjid Benchikh, Ramdane Babadji, Jean-Robert Henry, Frank Frégosi, Mohamed Karem, Baudouin Dupret, Omar Bendourou, Rafâa Ben Achour, Jean-Claude Santucci, Pierre-Sateh Agate, Bülent Tan r, Bernard Botiveau.
} 
Justice in Belgium: Legal Anthropology and Immigration) (9), she addresses theoretical issues related to legal anthropology (conflict resolution, representations and strategies, methodology) and gives a thorough analysis of the field research she conducted as an attorney. Combining law and ethnography, this study shows the value of works that consider the legal object from both an external and internal point of view, focusing on practices and discourses while embedding them in their legal and institutional framework. Foblets's book, moreover, bridges the gap between Anglo-American and continental anthropology, drawing upon a huge field of references. Despite a strong culturalist stance that leads Foblets to speak of "latent legal knowledge" and of "legal acculturation," this book reveals how law is transformed and shaped by interpretations of legal systems, even though people have not directly experienced them. The same author directed a collective research project on the legal conflicts of migrant women in North Africa. The fruits of this research are published under the title Femmes marocaines et conflits familiaux en immigation: quelles solutions juridiques appropriées? (Moroccan Women and Family Conflicts in Immigration: Some Appropriate Legal Solutions?) (14). ${ }^{9}$ This is a more practical book that shows how legal anthropology can be used to adapt the law to situations with which it was not prepared to cope.

The Cairo-based CEDEJ is an important hub for French-speaking research on normative phenomena in the Middle East. Many doctoral studies and collective books have been produced in this environment, testifying to the sustained attention given to law from a socio-political perspective. These young scholars have already made a significant contribution to the literature on this theme. Their basic convictions are these. First, area studies must be "banalized," meaning that the study of "exotic" local settings must abide by the same tools, criteria, paradigms, theoretical framework as they are used for studying our "Western" environment. This is a very classical criticism addressed to Orientalism, but it deserves attention since one can observe a constant tendency to refer knowledge about these societies to the cultural specificities of the area and not to the academic disciplines to which such knowledge belongs. Second, an interdisciplinary approach to legal phenomena must be promoted, with the consequence that law cannot be considered from the dogmatic point of view of jurisprudence and or of legal Orientalism. This conviction leads to refusing to give any overarching status to notions and concepts such as Shari'ah that would otherwise bias the analysis. Such a "de-essentializing" process means that the focus is on the changes and variations in uses of this concept, as well as on the mechanisms that are not considered per se for their

\footnotetext{
${ }^{9}$ List of contributors: Marie-Claire Foblets, Nouhza Bensalah, Felice Dassetto, Jean-Yves Carlier, Jinske Verhellen and Johan Erauw.
} 
inner meaning. Both the internal and external points of view are combined so as to take them seriously in the larger context of their concrete manifestation. Third, this approach stems from the firm idea that the long way roundfocusing on other legal contexts - can be very fruitful for the study of the normative and legal phenomena in general. It insists that historical and cultural phenomena must be assessed from a symmetrical point of view, and it refuses to consider other times and places in a radically relativist attitude. Following these assumptions, this perspective claims that the results of its research on Middle Eastern legal contexts are directly relevant to the current theoretical, sociological, and anthropological debate on the question of normative, whatever its historical and cultural context.

Among the main productions of this small team, many doctoral theses have already been published or will be published shortly. The first of these theses was my own, published under the title Au nom de quel droit. Répertoires juridiques et référence religieuse dans la société égyptienne musulmane contemporaine (In the Name of What Law? Legal Repertoires and Religious Reference in Contemporary Muslim Society in Egypt). (12). This constitutes an effort to consider law from the perspective of the many actors who contribute to its construction and who are acting by using and referring to the many legal repertoires at their disposal within a constraining frame. Drawing from diverse materials including court rulings, interviews, jurisprudential works, field observation and legal literature, my dissertation aims at showing how Islamic rules are the construct of current and local interactions that substantiate linguistic forms related to former legal systems.

Another thesis is Murielle Paradelle's Des usages d'un répertoire normatif en politique étrangère. La place et le rôle de la shari'ah islamique dans la pratique international des Etats musulmans (On the Uses of a Normative Repertoire in Foreign Politics: The Place and Role of Islamic Shari'ah in the International Practice of Muslim States) (21). It focuses on the uses of the Islamic repertoire in the determination of foreign policy in Islamic states, particularly in Egypt, Saudi Arabia, Iran, Libya, Sudan and Pakistan. It questions the idea of an underlying conception of foreign affairs specific to Muslim states by closely examining the so-called classical Islamic theory of public international law and the specific practices of the organization of the Islamic Conference. This work really opens new doors in the sociological study of international law.

The third thesis completed under the auspices of CEDEJ is Nathalie Bernard-Maugiron's La Haute Cour constitutionelle égyptienne et la protection des droits fondamentaux (The Supreme Constitutional Court of Egypt and the Protection of Fundamental Rights) (23). This is a purely legal analysis of the case law of the Supreme 
Constitutional Court of Egypt concerning public freedoms. It provides a complete introduction to the court, its adjudication and the normative role of the judge in his interpretation. It also raises the question of the relationship between the constitutional judiciary and its political environment. But its main value comes from the fact that it deals with an Arab judicial institution within the same aims and tools as those used for studying the American Supreme Court or the French Conseil constitutionnel. This kind of legal work has set the standard for future research in the field. It should be considered as a compulsory prerequisite to research on the socio-political dimension of Arab law in any context.

A number of jointly authored books or special issues of reviews are directly or indirectly related to the activities of this team. First among them, Droits et sociétiés dans le monde arabe. Perspectives socioanthropologiques (Laws and Societies in the Arab World: Socio-Anthropological Perspectives) (13) is an attempt to refer systematically study of law to its very specific social and historical context. ${ }^{10}$ Neither Islamic law nor law per se is addressed so as to make an inventory of their provisions. Rather, the effort is to scrutinize the normative dynamics in which law is necessarily embedded. A special issue of the review Droit et société (15) has been devoted to the idea of the necessity of conducting non-culturalist sociological studies of the norm in the Arab context. ${ }^{11}$ Although the contributions do not directly address the topic, they all reflect the possibility of referring the study of law in Arab societies to theoretical debates that are shared by a broader, non-culturally centered scholarship.

Two issues of the review edited by CEDEJ have been devoted to law in Egypt from an interdisciplinary point of view merging history, political and social sciences. The first one, Droits d'Egypte: histoire et sociologie ("Laws of Egypt: History and Sociology") (19), groups individual contributions addressing various aspects of Egyptian modern legal history and issues related to current judicial practices and the uses of customary law as well as a whole set of translated documents and book reviews. ${ }^{12}$ The second issue, entitled Le Prince et son juge: droit et politique dans l'Egypte contemporaine (The Prince and His Judge: Law and Politics in Contemporary Egypt) (22), is

\footnotetext{
${ }^{10}$ List of contributors: Norbert Rouland, Baudouin Dupret, Jean-Noël Ferrié, Murielle Paradelle, Jan Goldberg, Mohamed Afifi, Léon Buskens, Lawrence Rosen, Gilles Boëtsch, Sarah Ben Néfissa, Aymé Lebon, Bernard Botiveau. Nathalie Bernard-Maugiron.
}

${ }^{11}$ List of contributors: Baudouin Dupret, Brinkley Messick, Mohamed Nachi, Kilian Bülz, and Armando Salvatore.

${ }^{12}$ List of contributors: Baudouin Dupret, Nathalie Bernard-Maugiron, Khaled Fahmy, Ruud Peters, Jan Goldberg, Jorn Thielmann, Armando Salvatore, Kilian Bülz, Hans Christian Korsholm Nielsen, Murielle Paradelle, Hervé Bleuchot, and Maurits Berger. 
a collection of contributions devoted to the Supreme Constitutional Court and its political environment. ${ }^{13}$ It addresses the main questions this institution had to tackle during its two decades of existence: property, reference to Shari'ah, personal status, and public freedoms.

During the past decade there have been several contributions to the study of law in the Middle Eastern context from a sociological, historical and even philosophical perspective. These books and theses are the result of endeavors that are relatively isolated vis-à-vis the main trends identified above in this review. It is for this reason that I group them here in the final section of this essay.

Yadh Ben Achour, a prominent Tunisian legal practitioner and political and legal philosopher, has contributed several studies to law in Islam, legal reform, the philosophy of the modern state in newborn nations. For example, Politique, religion et droit dans le Monde arabe arabe (Politics, Religion and Law in the Arab World) (5) is an essay on legal dynamics in the Arab context. This book is one of the few that combines a critical perspective with an inner knowledge of law.

Sami A. Aldeed Abu-Sahlieh's Les musulmans face aux droits de l'homme (Muslims and Human Rights) (10), is not in the same league as the work of Ben Achour. Abu-Sahlieh's book represents a trend that is flawed both scientifically and ethically. A militant attack on Arab countries and on Islam should not be equated with scholarly competence. Abu-Sahlieh completely ignores the necessary historical, political and sociological dimensions of the study of law. He points to the most marginal and wicked aspects of Arab Muslim societies in order to fuel a polemical argument against any kind of religious claim in the realm of law and against the adaptation of laws to the presence of Muslim communities in Europe.

Contrary to this approach which is impervious to the social conditions of legal constructs and practices, a young Tunisian scholar recently completed an excellent doctoral thesis on the notion of justice in a comparative perspective. Mohamed Nachi's Le sens de la justice. Etude comparative des formes de jugement et de justification en Tunisie et en France (The Sense of Justice: A Comparative Study of the Forms of Judgment and of Justification in Tunisia and France) (20) constitutes the first attempt to make use of the communitarian theories of justice in the study of the sense of justice in Tunisia, and to compare the results in this context with another he conducted in France. The result is both theoretically and empirically impressive. Nachi provides us with a huge introduction to the

\footnotetext{
${ }^{13}$ List of contributors: Nathalie Bernard-Maugiron, Baudouin Dupret, Bettina Dennerlein, Gamal Ibrahim Abd el-Nasser and Enid Hill.
} 
theories of justice in Islamic thought as well as in current debates, and then proceeds to a very refined analysis of his field research. One might, however, question the connection that he seems to draw between the practical results of his empirical survey and the so-called "Islamic theory of justice," as it appears from his reading from classical sources.

The late Jacques Lafon, a French professor of legal history, also contributed several studies to the history of legal reforms in the Ottoman Empire and the introduction of codification. A strong interest in the status of minorities in the Middle East led him to write an essay on the status of Jerusalem (18). Although this book is well documented, it strongly reflects some of the old Orientalist prejudices.

Joel Colin's L'enfant endormi dans le ventre de sa mère. Etude ethnologique et juridique d'une croyance au Maghreb (The Infant Sleeping in Its Mother's Womb: An Ethnological and Juridical Study of a Belief in the Maghreb) (16) is a revision of a doctoral thesis in anthropology. It focuses on a North African folk belief in the capacities of a fetus to fall asleep in its mother's womb especially at the time of their father's absence from the home. This study reviews legal, Islamic and Orientalist literature, examines colonial case-law in Algeria and Morocco and attempts to analyze current case-law in these countries. Although it suffers from many theoretical flaws, in particular in its anthropological treatment of the phenomenon, it provides us with the first comprehensive essay on a much too much folkloricized issue.

Finally, I would like to focus on the publication in French of the proceedings of an international colloquium that took place in Cairo in 1998 celebrating the fiftieth anniversary of the Civil Code drafted by the prominent jurist 'Abd al-Razzaq al-Sanhuri. Organized by the Egyptian Ministry of Justice, Actes du congrès international du cinquantenaire du Code civil Ègyptien (1948-1998) (Proceedings of the International Congress of the Fiftieth Anniversary of the Egyptian Civil Code, 1948-1998) (17) is a collection of articles that combine pure legal contributions with more philosophical and historical ones. ${ }^{14}$ As is often the case with this genre, the end product is spotty and uneven. Nevertheless, it is a valuable contribution to the knowledge of Sanhuri's work and of the widespread impact of the Egyptian Civil Code throughout the world.

${ }^{14}$ List of contributors: Ibrahim Hussein Radwan, Abdel Meneem El Badrawi, Jacques Lafon, Sami Aldeeb Abu Sahlieh, Iskandar Ghattas, Ahmed Yousry, William Souliman Kelada, Mohamed Nour Farahat, Gassem Aly El Chamsi, Galal Mohamed Ibrahim, Abdel Rassoul Abdel Reda, Borham Mohamed Atallah, Hicham Sadek, Ahmed Abdel Karim Salama, Jean-Louis Harlepin, Samir Abdel Malak Mansour, Houssam El Din El Ahnawi, Fathi Abdel Rahim Abdallah, Mohamed El Chahhat El Guendi, Kamal Hamdi, Ibrahim Ahmad Ibrahim, Ahmed Hassam El Borai, Fathi Waly, Mohamed Nour Shehata, Nabila Raslan. 


\section{BIBLIOGRAPHY}

1) Maurice Flory and Jean-Robert Henry, eds. L'enseignement du droit musulman (The Teaching of Islamic Law). Marseille: Editions du CNRS, 1989.

2) 1989, Droit et environnement social au Maghreb. (Law and Social Environment in the Maghreb). Paris-Casablanca: Editions du CNRS-Fondation Abdul-Aziz al Saoud, 1989. Jean-Robert Henry "Le changement juridique dans le monde arabe: jalons théoriques." ("Juridical Change in the Arab World: Theoretical Signposts”), Droit et Société No. 15 (1991).

Nabil 'Abd al-Fattah and Bernard Botiveau, eds., Politiques législatives: Egypte, Tunisie, Algérie, Maroc. (Legislative Politics: Egypt, Tunisia, Algeria and Morocco). Cairo: Dossiers du CEDEJ, 1994.

Yadh Ben Achour, Politique, religion et droit dans le monde arabe (Politics, Religion and Law in the Arab World). Tunis, Céres Productions, 1992.

Bernard Botiveau, Loi islamique et droit dans les sociétés arabes. Mutations des systèmes juridiques du Moyen-Orient. (Islamic Law and Positive Law in Arab Societies: Mutations of Judicial Systems in the Middle East). Paris: Karthala-IREMAM, 1993.

Mohamed Al-Ahnaf, Bernard Botiveau, and Jocelyne Cesari, eds., "Sur les usages politiques du droit" ("On the Political Uses of Law"), Maghreb Machrek No 142 (1993).

Hervé Bleuchot, Les cultures contre l'homme? Essai d'anthropologie historique du droit pènal soudanais (Cultures Against Humanity? An Essay of Historical Anthropology on Sudanese Criminal Law). Aix-enProvence, Presses universitaires d'Aix-en-Provence, 1994.

Marie-Claire Foblets, Les familles maghrébines et la justice en Belgique, Anthropologie juridique et immigration. (Maghrebian Families and Justice in Belgium: Legal Anthropology and Immigration). Paris: Karthala, 1994.

Sami Abu-Sahlieh, Les musulmans face aux droits de l'homme (Muslims and Human Rights). Bochum: Winker, 1996.

Ahmed Mahiou, ed., L'Etat de droit dans de monde arabe (The Rule of Law in the Arab World). Paris: CNRS Editions, 1997.

Baudouin Dupret, Au nom de quel droit. Répertoires juridiques et référence religieuse dans la société égyptienne musulmane contemporaine (In the Name of What Law? Legal Repertoires and Religious Reference in Contemporary Muslim Society in Egypt). Paris: Maison des sciences de l'homme (coll. Droit et Société), 2000 [1997].

Gilles Boëtsch, Baudouin Dupret, and Jean-Noël Ferrié, eds., Droits et sociétés dans le monde arabe. perspectives socio-anthropologiques (Laws and Societies in the Arab World: Socio-Anthropological Perspectives). Aix-en-Provence: Presses Universitaires d'Aix-Marseille, 1997.

Marie-Claire Foblets, ed., Femmes marocaines et conflits familiaux en immigration: quelles solutions juridiques appropriées? (Moroccan Women and Family Conflicts in Immigration: Some Appropriate Juridical Solutions?). Antwerpen: Maklu, 1998

Baudouin Dupret, ed., "Une sociologie non culturaliste de la norme en contexte arabe" ("A NonCulturalist Sociology of the Norm in the Arab Context”). Droit et société No. 39 (1998)

Joel Colin, L'enfant endormi dans le ventre de sa mère. Etude ethnologique et juridique d'une croyance au Maghreb (The Infant Sleeping in Its Mother's Womb: An Ethnological and Juridical Study of a Belief in the Maghreb). Perpignan: CERJEMAF/Presses Universitaires de Perpignan, 1998.

Direction générale de la coopération internationale et culturelle, ed., Actes du congrès international du cinquantenaire du Code civil Ègyptien (1948-1998) (Proceedings of the International Congress of the Fiftieth Anniversary of the Egyptian Civil Code, 1948-1998) Cairo: Ministère de la Justice, République Arabe d'Egypte, 1998.

Jacques Lafon, Jérusalem. Paris: Montchrestien, 1998.

Baudouin Dupret and Nathalie Bernard-Maugiron, eds., "Droits d'Egypte: histoire et sociologie," ("Laws of Egypt: History and Sociology”) Egypte-Monde arabe, No. 34 (1998)

Mohamed Nachi, Le sens de la justice. Etude comparative des formes de jugement et de justification en Tunisie et en France. Thèse pour l'obtention du titre de docteur en sociologie, Ecole des Hautes Etudes en Sciences Sociales, 1998 (The Sense of Justice: A Comparative Study of the Forms of Judgment and of Justification in Tunisia and France, Ph.D. Dissertation).

Murielle Paradelle, Des usages d'un répertoire normatif en politique étrangère. La place et le rôle de la shari'ah islamique dans la pratique internationale des Etats musulmans. Thèse pour l'obtention du titre de docteur en sciences politiques, Institut d'Etudes Politiques d'Aix-en-Provence, 1999 (On the Uses of a 
Normative Repertoire in Foreign Politics: The Place and Role of Islamic Shari'ah in the International Practice of Muslim States. Ph.D. Dissertation).

22) Nathalie Bernard-Maugiron, Baudouin Dupret (eds.), "Le Prince et son juge: droit et politique dans l'Egypte contemporaine (The Prince and His Judge: Law and Politics in Contemporary Egypt). EgypteMonde arabe, nouvelle série, No 2 (1999)

23) Nathalie Bernard-Maugiron, La Haute Cour constitutionelle égyptienne et la protection des droits fundamentaux. Thèse pour l'obtention du titre de docteur en droit, Université de Nanterre, 1999 (The Supreme Constitutional Court of Egypt and the Protection of Fundamental Rights, Ph.D. Dissertation). 